\title{
Pelatihan Teknis Aplikasi Parenting Control Sebagai Media Pengawas Penggunaan Gadget Pada Anak Untuk Ibu-Ibu PKK di Kecamatan Baturraden
}

\author{
Ika Romadoni Yunita ${ }^{1}$ \\ Universitas Amikom Purwokerto, ikarom@amikompurwokerto.ac.id \\ Fiby Nur Afiana ${ }^{2}$ \\ Universitas Amikom Purwokerto, fiby@amikompurwokerto.ac.id \\ Primandani Arsi ${ }^{3}$ \\ Universitas Amikom Purwokerto, ukhti.prima@amikompurwokerto.ac.id
}

\begin{abstract}
Abstrak
Pengenalan teknologi/gadget pada anak tidak salah, akan tetapi diharapkan peran orang tua untuk turut serta mengawasi penggunakan gadget pada anak. Penggunaan gadget tanpa pengawasan memberikan beberapa dampak negatif terhadap interaksi sosial seperti mereka lebih nyaman menggunakan gadget daripada berinteraksi atau bermain dengan teman sebayanya. Namun terdapat juga pengaruh positif pengenalan gadget pada anak seperti dapat mengasah kemampuan kognitif, belajar tanggap teknologi dan berfikir lebih kreatif. Pengenalan teknologi/gadget pada anak tidak salah, akan tetapi diharapkan peran orang tua untuk turut serta mengawasi penggunakan gadget pada anak. Berdasarkan survey yang dilakukan di Dusun II Purwosari Kecamatan Baturraden, 93\% mengatakan bahwa para ibu tidak mengetahui atau tidak paham mengenai aplikasi parenting control yang dapat diinstal di gadget untuk mengontrol penggunaan gadget pada anak. Tujuan dari kegiatan pengabdian ini para ibu dapat melakukan pengawasan terhadap gadget yang digunakan anak melalui salah satu aplikasi parenting control Google Family Link yang terdiri dari 2 versi untuk orang tua dan anak dan dapat diunduh secara gratis di play store. Dengan pengabdian ini Orang tua tidak membiarkan begitu saja anak menggunakan gadget tanpa pengawasan karena bisa berdampak buruk terhadap tumbuh kembang anak baik secara fisik maupun psikis.
\end{abstract}

Kata Kunci: Gadget, parenting control, google family link.

\begin{abstract}
The introduction of technology / gadgets in children is not wrong, but it is expected that the role of parents to participate in overseeing the use of gadgets in children. The use of gadgets without supervision provides several negative impacts on social interactions as they are more comfortable using gadgets than interacting or playing with their peers. But there is also a positive influence on the introduction of gadgets in children such as being able to hone cognitive abilities, learn responsive technology and think more creatively. The introduction of technology / gadgets in children is not wrong, but it is expected that the role of parents to participate in overseeing the use of gadgets in children. Based on a survey conducted in Hamos II Purwosari, Baturraden District, 93\% said that mothers did not know or did not understand the application of parenting control that can be installed in gadgets to control the
\end{abstract}


use of gadgets in children. The purpose of this community service activity is that mothers can supervise the gadgets that children use through one of the Google Family Link parenting control applications, which consists of 2 versions for parents and children and can be downloaded for free at the play store. With this dedication, parents do not let children use gadgets without supervision because they can adversely affect the child's growth and development both physically and psychologically.

Keywords: Gadgets, parenting control, google family link.

\section{Pendahuluan}

Beberapa penelitian menunjukkan bagaimana pengaruh gadget pada anak di usia dini, dimana usia dini dikatakan dari usia 0 hingga 8 tahun(Rosyid Ridho, Markhamah, \& Darsinah, 2015). Pengaruh yang didapatkan lebih banyak ke arah negatif, seperti penelitian yang dilakukan oleh Novitasari dan Nurul(Novitasari \& Khotimah, 2016), bahwa penggunaan gadget memberikan dampak terhadap interaksi sosial seperti mereka lebih nyaman menggunakan gadget daripada berinteraksi atau bermain dengan teman sebayanya. Asif dan Farid(Asif \& Rahmadi, 2017) juga mengatakan terdapat hubungan antara tingkat kecanduan gadget dengan gangguan emosi dan perilaku anak, gangguan emosi dan perilaku merupakan bahaya yang serius dalam perkembangan dan dapat menurunkan produktivitas serta kualitas hidup anak. Survey yang dilakukan theAsianParent Insight bersama Samsung Kidstime melalui Mobile Device Usage Among Young Kids yang diselenggarakan pada awal tahun 2014. Sebanyak 2500 orang tua di Singapura, Thailand, Indonesia, Malaysia, dan Filipina menjadi responden pada survey ini.

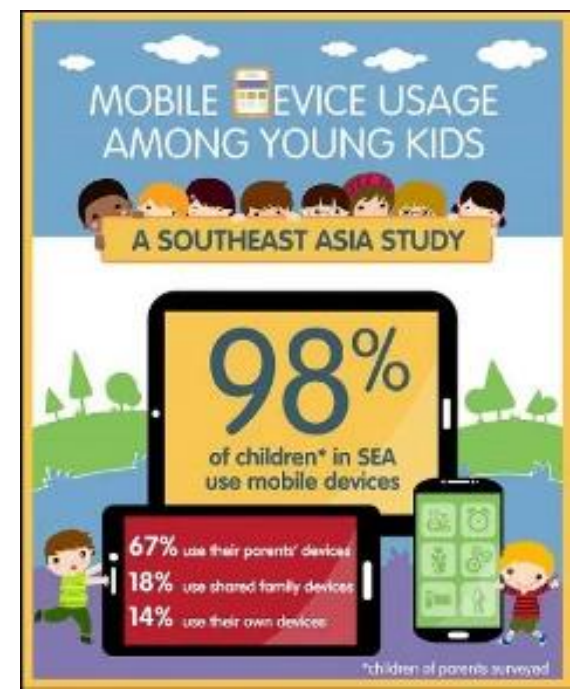

Gambar 1. Survey Penggunaan Gadget Pada Anak

Dengan hasil 98\% responden memperbolehkan anaknya menggunakan smartphone /tablet/gadget, di mana Singapura menempati urutan teratas untuk jumlah anak-anak yang menggunakan gadget orangtuanya(Nithy, 2015).

Selain pengaruh negatif, banyak juga pengaruh positif pengenalan gadget pada anak seperti dapat mengasah kemampuan kognitif, belajar tanggap teknologi dan berfikir 
lebih kreatif(Witarsa, Hadi, Nurhananik, \& Haerani, 2018). Pengenalan teknologi/gadget pada anak tidak salah, akan tetapi diharapkan peran orang tua untuk turut serta mengawasi penggunakan gadget pada anak(Lestari, Riana, \& Taftazani, 2015). Banyak sekali aplikasi mobile yang dapat membantu orang tua untuk memasang larangan pada aplikasi mobile yang dieksplor, memonitor pemakaian telepon, internet serta menyeleksi aplikasi mobile mana yang boleh dan tidak boleh digunakan anak. Aplikasi tersebut antara lain Kids Place, Kakatu Parental Control, Kid's Shell, Family Time Parental Control, Kids Zone Parental Control, Screen Time Parental Control, Google Family Link dan masih banyak aplikasi lainnya yang dapat diundung secara gratis di play store dan App Store. Tapi permasalahannya tidak semua orang tua tahu atau paham aplikasi parenting control tersebut. Berdasarkan survey yang dilakukan di Dusun II Purwosari Kecamatan Baturraden, 93\% mengatakan bahwa para ibu tidak mengetahui atau tidak paham mengenai aplikasi parenting control yang dapat diinstal di gadget untuk mengontrol penggunaan gadget pada anak. Mereka cenderung membiarkan saja anaknya menggunakan gadget tanpa ada pengawasan langsung atau pengawasan melalui aplikasi parenting control. Para orang tua khususnya ibu, memberikan gadget pada anaknya agar mereka diam dan para ibu bisa mengerjakan pekerjaan rumah lainnya tanpa diganggu aktifitas bermain anak. Hal ini tentu sangat tidak baik bagi tumbuh kembang anak khususnya anak usia dini.

\section{Metode Pelaksanaan}

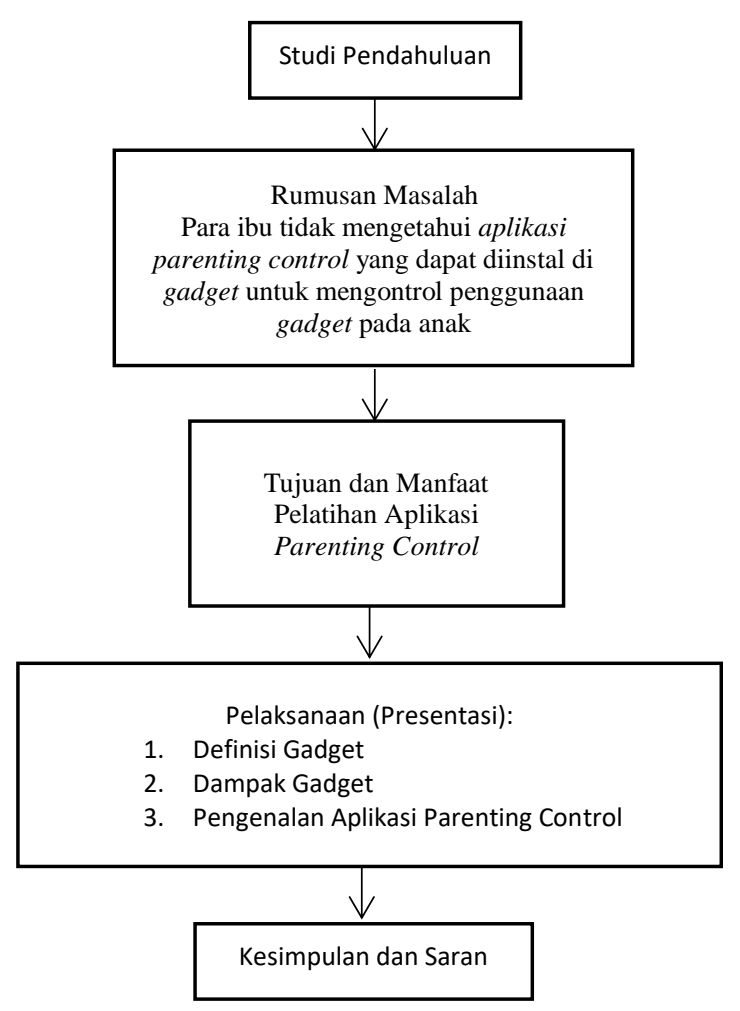

Gambar 2. Tahapan Pelaksanaan 
Metode yang digunakan pada pengabdian ini adalah metode presentasi dan pendampingan praktek pada Ibu-ibu PKK di Kecamatan Baturraden. Tahapan presentasi dimulai dengan pemaparan apa itu gadget, bagaimana dampak negatif bila penggunaan gadget tanpa diawasi orang tua. Tahapan berikutnya memberikan contoh - contoh aplikasi parenting control yang bisa digunakan. Salah satunya aplikasi Google Family Link. Peserta juga diajarkan bagaimana cara menginstal dan menggunakan aplikasi Google Family Link.

\section{Hasil dan Pembahasan}

Kegiatan Pengabdian Kepada Masyarakat pada Ibu-ibu PKK di Kecamatan Baturraden dapat berjalan dengan lancar dan seluruh kegiatan dapat terealisasikan. Masyarakat dalam hal ini Ketua, pengurus dan anggota PKK memberi dukungan dan respon yang baik, mereka antusias mengikuti kegiatan yang berlangsung. Kepala Desa Purwosari juga menyambut baik kegiatan ini bahkan mendukung diterapkanya parenting kontrol guna pengawasan orang tua terhadap penggunaan gadget anak-anaknya.

Pelaksanaan pengabdian dilaksanakan tanggal 5 September 2019 di Balai Desa Purwosari dengan dihadiri 71 peserta. Pembicara yang terlibat dalam kegiatan ini adalah Ika Romadoni Yunita, S.Kom, M.MSI, Primandani Arsi, SST.,M.Kom dan Fiby Nur Afiana, S.Kom, M.MSI.

Para ibu khususnya ibu-ibu di Kecamatan Baturraden cenderung membiarkan anaknya menggunakan gadget tanpa ada pengawasan langsung atau pengawasan melalui sebuah aplikasi. Setiap anak hanya difasilitasi Gadget atau sejenisnya, tapi apakah para orang tua mengetahui dampaknya bila penggunaan gadget tidak diawasi orang tua langsung? Karena tanpa pengawasan orang tua, anak akan sesuka hati menggunakan gadget yang nantinya akan berdampak negatif seperti ketergantungan, ketidakstabilan emosi, obesitas, gangguan pendengaran hingga gangguan interaksi sosial. Hal ini terjadi karena mereka tidak mengetahui bahwa terdapat aplikasi parenting control yang dapat diunduh secara gratis di play store dan App Store, dimana aplikasi-aplikasi tersebut dapat membantu orang tua untuk mengontrol penggunaan gadget pada anak. Mereka hanya paham menggunakan teknologi/gadget sebagai alat komunikasi, hiburan atau bahkan game tanpa tau ada aplikasi lainnya yang lebih bermanfaat untuk mereka gunakan.

Melalui pengabdian ini, tim dosen Universitas Amikom Purwokerto berusaha memberikan pelatihan teknis dan pendampingan kepada warga Kecamatan Baturraden, khususnya ibu-ibu PKK untuk berperan aktif dalam mengawasai penggunaan gadget pada anak dengan pengawasan langsung atau dengan bantuan aplikasi parenting control. Saat ini banyak sekali aplikasi parenting control yang bisa di download secara gratis di play store salah satunya adalah Google Family Link yang terdiri dari 2 versi untuk orang tua dan anak. Pada langkah awal, akun Gmail orang tua akan ditetapkan sebagai "family manager", dengan proses berikutnya yang melibatkan kode pemasangan yang dihasilkan secara acak dari aplikasi Family Link 
for parents. Kemudian orang tua memasukkan kode pemasangan di aplikasi Family Link for children \& teens.

Setelah proses pemasangan selesai, sebagai orang tua bisa melakukan moderasi konten internet di smartphone Android yang digunakan anak. Beberapa fitur utama Family Link antara lain adalah memantau aplikasi yang digunakan dan durasi total penggunaannya, memantau unduhan aplikasi di Play Store, menentukan batas waktu penggunaan smartphone, memantau lokasi anak dari sensor GPS. Melalui aplikasi Google Family Link, orang tua memegang kekuasaan penuh atas gadget yang dimiliki si anak karena gadget orang tua dan anak saling terhubung dan tidak bisa diputus sepihak. Para orang tua bisa mengetahui aplikasi apa saja yang digunakan anak, apa saja content yang dibuka, dimana lokasi anak saat ini hingga memberi batasan sampai pukul berapa anak boleh mengakses gadget.

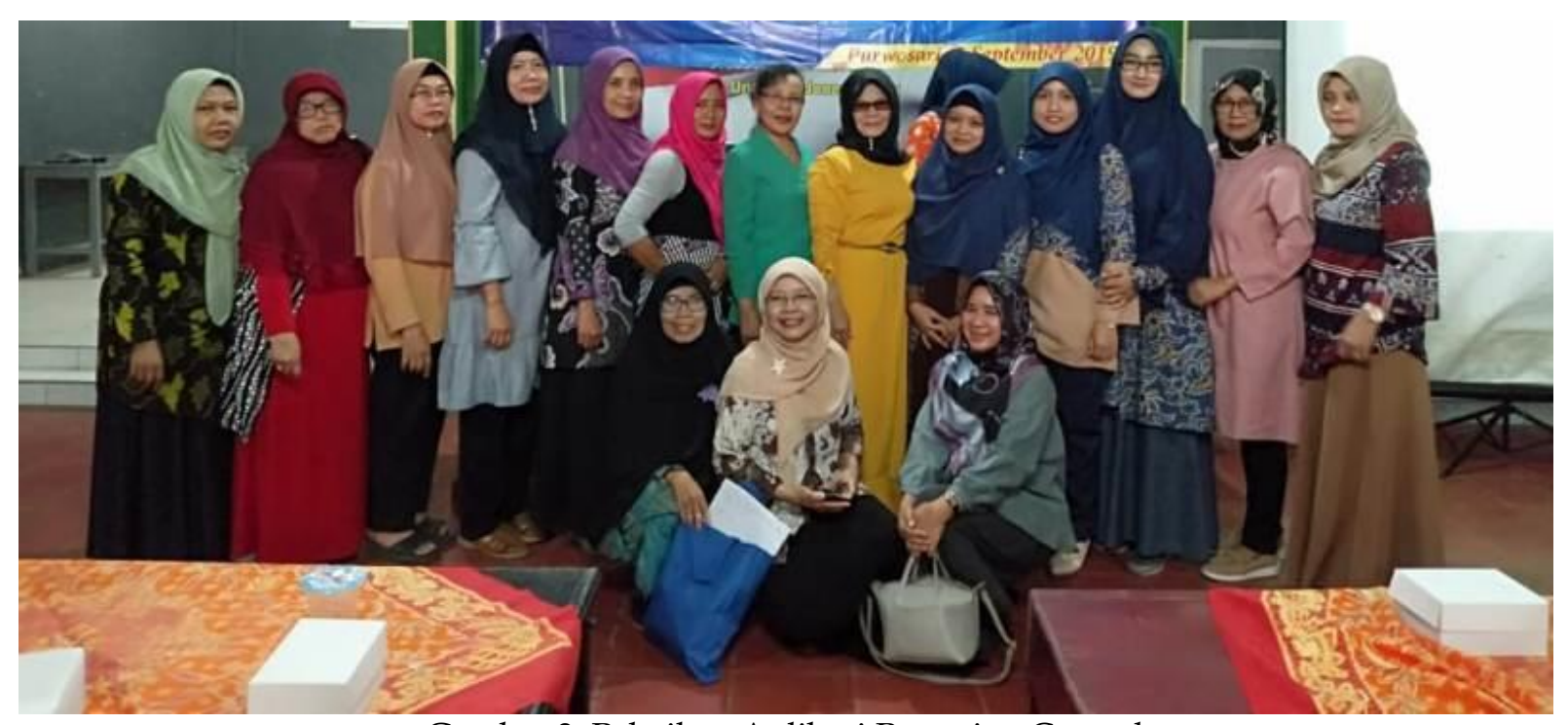

Gambar 3. Pelatihan Aplikasi Parenting Control

\section{Simpulan dan Rekomendasi}

Kegiatan pengabdian kepada masyarakat berupa Pelatihan Teknis Aplikasi Parenting Control Sebagai Media Pengawas Penggunaan Gadget Pada Anak Untuk Ibu-Ibu PKK Di Kecamatan Baturraden telah terlaksana sesuai dengan rencana dan tujuan yang ingin dicapai. Memberikan pengetahuan kepada peserta yang terdiri dari Ibu Ketua, pengurus dan anggota PKK cara untuk mengontrol penggunaan gadget pada anak melakui aplikasi parenting control Google Family Link. Orang tua tidak membiarkan begitu saja anak menggunakan gadget tanpa pengawasan karena bisa berdampak buruk terhadap tumbuh kembang anak baik secara fisik maupun psikis. Kedepannya tidak hanya aplikasi Google Family Link yang diperkenalkan namun aplikasi parenting control lainnya yang dapat diunduh secara gratis di play store.

\section{Daftar Pustaka}

Asif, A. R., \& Rahmadi, F. A. (2017). Hubungan Tingkat Kecanduan Gadget dengan Gangguan Emosi dan Perilaku Remaja Usia 11-12 Tahun. Jurnal Kedokteran 
Diponegoro,

6(2),

$148-157$.

Retrieved

from

https://ejournal3.undip.ac.id/index.php/medico/article/view/18529

Lestari, I., Riana, A. W., \& Taftazani, B. M. (2015). Pengaruh Gadget Pada Interaksi

Sosial Dalam Keluarga. Prosiding Penelitian Dan Pengabdian Kepada Masyarakat, 2(2), 204-209. https://doi.org/10.24198/jppm.v2i2.13280

Nithy, T. (2015). Survey Tentang Smartphone \& Tablet. Retrieved from https://id.theasianparent.com. website: https:/ /id.theasianparent.com.

Novitasari, W., \& Khotimah, N. (2016). Dampak Penggunaan Gadget Terhadap Interaksi Sosial Anak Usia 5-6 Tahun. Jurnal PAUD Teratai, 05(03), 182-186. https://doi.org/10.1016/j.jns.2003.09.014

Rosyid Ridho, Markhamah, \& Darsinah. (2015). Pengelolaan Pembelajaran Pendidikan Anak Usia Dini (PAUD) di KB "Cerdas" Kecamatan Sukorejo Kabupaten Kendal. Jurnal Penelitian Humaniora, 16(02), 59-69.

Witarsa, R., Hadi, R. S. M., Nurhananik, \& Haerani, N. R. (2018). Pengaruh Penggunaan Gadget Terhadap Kemampuan Interaksi Sosial Siswa Sekolah Dasar. Pedagogik, 1(1), 9-20. 